\title{
Adaptation to Climate Change and Variability by Gender in Agro-pastoral Communities of Tanzania
}

\author{
Eliya E. Mtupile ${ }^{1}$, Emma T. Liwenga $^{2}$ \\ ${ }^{1}$ Secure Livelihoods Department, VSO Tanzania \\ ${ }^{2}$ Institute of Resource Assessment, University of Dar es Salaam, Tanzania
}

\begin{abstract}
Gendered division of responsibilities in agropastoral societies of semi-arid parts of Tanzania influence the exposure of women and men differently into various experiences, skills, knowledge, technology and resources in similar ways that they expose them to climate risks and opportunities. This paper examines gender based vulnerability and adaptation strategies to climate change in these communities. The study was undertaken in two villages of Chamwino District in Tanzania. Data collection involved focus group discussions, key informant interviews and household interviews (5\%). Rainfall and temperature data for the past 30 years were also analysed. Indicators of climate change and variability were revealed from both climate and social studies. Annual mean rainfall decreased from $700 \mathrm{~mm}$ in 1980 to $490 \mathrm{~mm}$ in 2010 while average temperatures were increasing steadily. The findings indicate that recent climatic changes have favoured pest and diseases, which affects crops, livestock and people. Late onset and early end of rain season were also recorded which lengthened the hot season of the year and early drying of water sources. It was further established that, the change in gendered roles affected women and girls more than men and boys because activities related to chores that are women roles were most affected. Responses to climatic stresses also varied by sex because they had been exposed to different skills and experiences. Lack of resources in female headed households increased severity to impacts and hindered their capacity to overcome stresses.
\end{abstract}

Keywords - Gender, Climate Change, Climate Variability, Adaptations, Tanzania.

\section{INTRODUCTION}

Scientific evidence have indicated that climate change and variability is really happening, affecting natural and human systems, especially in dryland and semi-arid areas (IPCC, 2007). In the drylands of the 'tropics and sub-tropics' where most crops are at their maximum climate tolerance, and particularly in non-irrigated farmlands, severe losses in production may result from even slight changes in climatic conditions (Olmos, 2001). However, the intensity of threats differs depending on geographical locations and at households and individual levels. Individuals of the same community or household may be affected differently depending on their roles (Heijmans, 2001; Olmos, 2001). Likewise, their responses may also vary due to their previous experiences, available resources, knowledge and skills (Rossi and Lambrou 2008; Nelson and Stathers, 2009). This has lead areas experiencing the inequalities especially those based on gender and where local norms regulate decisions, to devise adaptation strategies that differs between the households and individuals and making the entire adaptation process complex.

In the developing world, rural women comprise a larger portion $(80 \%)$ of all smallholder farmers (Ngigi, 2009; FAO, 2010), and the majority of these are responsible for all domestic chores in their households. In Tanzania, agriculture, livestock, water and forestry are important sectors in provision of the majority rural households' livelihoods. These same sectors are highly sensitive to changes in climate (URT, 2003; URT, 2006b). Furthermore, it is estimated that over $80 \%$ of all Tanzanians live in the rural areas practicing these activities. Effects on such sectors therefore are felt by the majority Tanzanians.

The projection of the Intergovernmental Panel on Climate Change (IPCC) (2007) is that, Sub Saharan Africa will warm up to $4^{\circ} \mathrm{C}$ come the end of this century. This projection points out higher warming in semi-arid areas than the rest. Likewise, semi-arid parts of central Tanzania are expected to get warmer with lower rainfall than the rest parts of the country (URT, 2003; URT, 2006b). Predicted impacts on farming and livestock systems due to this warming include a reduction in crop production of up to $80 \%-84 \%$ and losses in livestock production (URT, 2003; URT, 2006b; Paavola, 2003). The estimated mean reduction of $0-20 \%$ in precipitation is predicted to extend dry seasons and affect pasture for livestock (Paavola, 2003; Yanda and Mubaya, 2011). 
Gender inequalities in resource ownership, in decisions and roles in households are also high in agro-pastoral communities of central Tanzania, and particularly in Dodoma Region. Rural communities in Dodoma have been traditionally agro-pastoralists; depending on the two major resources, that is, land and livestock for their livelihoods. These resources are mainly passed on to sons. Furthermore, most key decisions are made by husbands in those households. During a divorce the widow can be expected to leave the house without anything from the husband. The Tanzanian Law requires children younger than seven years to stay with their mothers before they go to live with their fathers. At this time, the widow who is land less and without livestock faces a difficult time to feed her family; and the situation is more serious in the context of climate change and variability. According to UNDP (2009), inequality in resource distribution amongst members of the society and the various social groups may enhance risks of climate change amongst those who are disadvantaged.

\section{MATERIALS}

2. 1 The Study Area.

\subsubsection{Geographical location and administrative set up}

This study was undertaken in two villages namely; Solowu and Mloda from Itiso and Makang'wa wards respectively, in Chamwino District (Figure 1). Chamwino District is one of six Districts of Dodoma Region. Other Districts within the region include Mpwapwa, Kondoa, Kongwa and Dodoma Municipal. Chamwino lies on the central plateau of Tanzania in the western bearing along Dar es Salaam road, latitudes $40^{\circ}$ to $70^{\circ}$ south and longitudes $35^{\circ}$ to $37^{\circ}$ north. Administratively, the District is divided into 5 divisions, 32 wards, 77 villages and 687 hamlets.

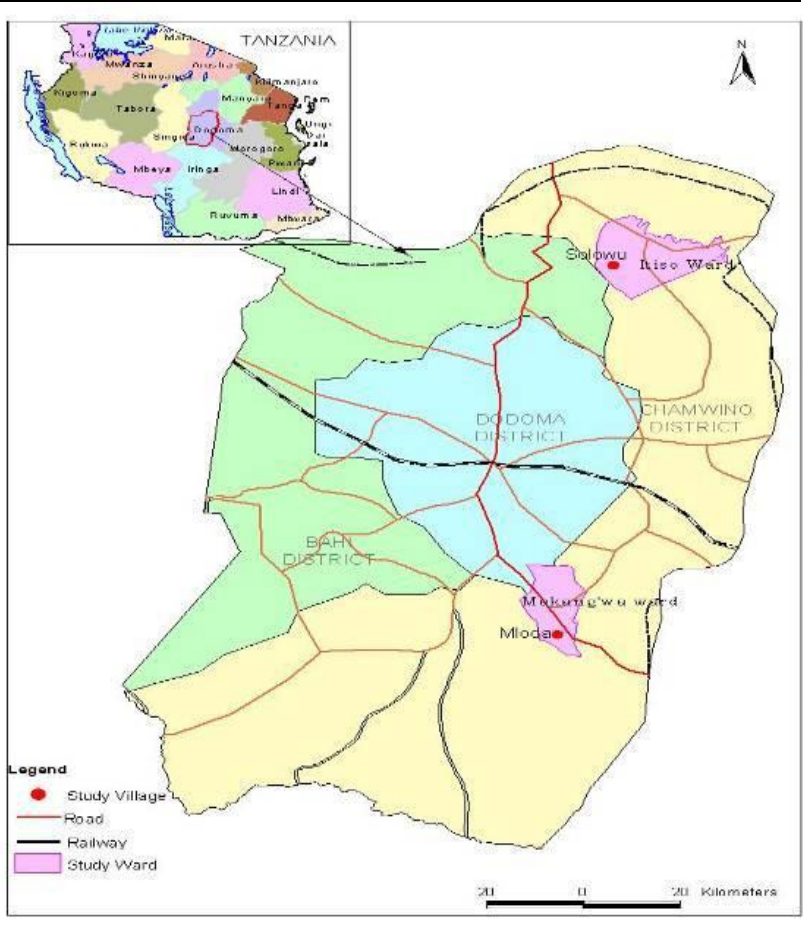

Fig. 1: Location Map of the Study Area

Source: GIS Laboratory, Institute of Resource Assessment (IRA), University of Dar es Salaam

\subsubsection{Demographic characteristics}

Chamwino District has a total area of 8,056 square kilometers and is inhabited by around 289,959 people, of which 151,091 are female and 138,868 male (Chamwino District Profile, 2011). The Population density is 36 people per square kilometre and the average household size is 4.15 (ibid). District population growth rate is estimated at $2.3 \%$ per annum, which is relatively lower than the national annual population growth of 2.9. Solowu village has a population of 3,331 people, confined into 486 households whereas Mloda has 4,226 people and 1,128 households. The average household size in the two study villages was 5.3. The District is dominated by the Gogo ethnic group although other groups such as Mang'ati, Zigua and Nyakyusa were found during the survey as migrants to the area. Both customary as well as legal means were very powerful in regulating resource ownership and use and men were more powerful in accessing these than women - similar to a situation observed by Ngware (1997).

\subsubsection{Biophysical features}

The central zone of Tanzania, where Chamwino District is located is generally dry. The climate differs within the District, but it is generally warm. Rains fall between November and May forming two peaks in December and March. The District falls in two agro-ecological zones based on soils and climatic conditions, which includes a 
very dry flat undulating plain lowland area receiving an annual rainfall of around $400 \mathrm{~mm}$ per annum. This part of the District is less populated and mainly used for grazing since rainfall is also very much unreliable. In this area crops such as sorghum, simsim, groundnuts and sunflower are grown (Chamwino District Profile, 2011). The other agro ecological zone has flat undulating hills. This area receives slightly higher rainfall between 550-650mm per annum (Chamwino District Profile, 2011). In this zone crops such as sorghum millet, maize, castor, groundnuts, tomatoes, onion and vines are grown. Livestock keeping is common but the increasing population size limits the number of animals (ibid).

The physical climate of the area is influenced by InterTropical Convergence winds, and due to its sentimentality, it has a long dry season and short intense wet season with erratic and unreliable rainfall patterns (Ngware et al. 1997, URT, 2006b). Soil fertility is variable, and always with localised salinity and hard pans (URT, 2006b). Vegetation cover of the area is characterized by thorn bushes that are either interspersed by sparse grass or bare ground in most parts of the area. Grass dominates some plains with miombo woodlands and inselbergs on the hilltops (Christianson, 1988, cited in Ngware 1997).

\section{METHODS}

This study employed several methods and techniques to collect qualitative and quantitative data from both primary and secondary sources. Relevant secondary data were obtained through reviews of published and unpublished literature from various sources including libraries and the internet. Data collected included climate, demographic, biophysical and policies related information. Results of the reviews were used to support arguments of the study findings.

3.1 Participatory Methods

Participatory methods including Focus Group Discussions (FGDs), Key Informant Interviews and Field Observations were used in this study to collect in-depth knowledge of local people's perception and experiences regarding climate change and variability; and also examining their inter-linkages with observed or perceived effects on the natural and human environments including livestock and agriculture. Such methods have the advantage of soliciting more information from local people; since they encourage participation and dialogue between local people and the researcher as well as amongst local people themselves (Lyimo and Kangalawe, 2010). Focus group discussions comprised of $12-15$ people. Since it is a gender study, particular attention was paid to consideration of representation of various social groups of male, female, ethnic, marginalised and age groups. Key informants were government workers at the District and ward levels - those with field experience on agriculture, livestock, environment and climate, as well as elderly people who happen to have seen changes in the villages for longer. During focus group discussions and key informant interviews, a checklist was prepared to answer questions related to local perceptions and experiences on climate variability, climate change and their impacts on both humans and biophysical resources as well as adaptation strategies and available assets that are being employed by various groups of individuals to respond to those threats. Physical observations were done along with focus group discussions, key informant and household interview to capture and crosscheck issues identified in the field.

\subsection{Sample Size and Household Interviews.}

In this study, households were defined as basic units of production and consumption in the villages and were used as units of analysis as suggested by Lyimo and Kangalawe (2010); and hence were used as study units during household surveys. $5 \%$ of all households in each study village were randomly selected; and were considered adequate to measure reliably the characteristics of respondents as suggested by UN (2005). This was also considered so because other tools were used to complement household interviews.

\subsection{Analysis of Climate Data}

Climate data, that is, daily and monthly records of rainfall and temperature for the past 30 years were also studied. Temperature data were obtained from the International Research Institute for Climate Prediction (IRI) specific for the study area while rainfall data were obtained from the Chamwino District library, recorded daily from the local weather station. These daily and monthly weather data were analysed and then extrapolated to draw periodic trends such as annual, decadal and longer.

\section{RESULTS AND DISCUSSION}

\subsection{Socio Economic Activities and Gender}

The main socio economic activities were sustenance farming and livestock keeping. Maize, millet, sorghum, sunflower and simsim were reported to be the main crops that were grown in the areas. Farming is mainly performed using hand hoe; although some families use oxen and a very few are changing to using tractors on occasional basis. Livestock keeping is by grazing where herds are taken on public lands normally far away from houses. More often, migration in search for grass to feed large herds of cattle during dry season is practiced. While both men and women undertook farm work; the larger portion of work is done by women who participate from farm preparation through planting, harvesting and marketing of crops. Men perform most of land preparation and 
marketing as well as cultivation when oxen is used. Women rarely involved in livestock keeping and management as this activity involved long walks, instead they were responsible to take care of children at home and performed almost all household chores. The findings further reveal that there were more female individuals $(58.3 \%)$ than male $(41.7 \%)$ in the study area. Females marry earlier at the age range between 16 and 19 while males marry at the age range 21 and 24 years. This has a connection with their exposure to education, whereby male are found to spend more time at school when compared to female who drop-off school to undertake other household activities. Similarly, boys spent more time in livestock keeping which kept them busy after completion of primary school education whilst girls were idle after completing primary education.

\subsection{Perceptions and Established Facts on Climate Change and Variability}

The findings of climate data analysed for the past 30 years as well as household interviews revealed indicators of climate change and especially climate variability. Temperature has been steadily increasing (Figure 1). Likewise, people perceive that this increase in temperature challenged the semi desert nature whereby it is too cold in nights and too hot during the day. Currently both day and nights were becoming hot. Rainfall trends show a sharp decline in intensity towards end of recording period in 2010 when compared to early 1980s (Figure 1). On the other hand, rainfall variability is higher in which fewer days receive heavy rainfall and there is a prolonged dry period in between. This was found to create unfavourable conditions to crops and even plants and grass. Therefore, the fall in crop yield that was also reported during interviews was most likely caused by this nature of rainfall behaviour. Furthermore, unlike in the 1980s where rainfall season started during the months of October or November and continued until April or May; towards 2010 the findings show that rains start in December and ends in March. This means that the rain season has been shortened. During interviews it was found that the time of the year that rivers run water has as well been reduced. This would most likely be linked to reduced rainfall and the shortened rain season. Moreover, it was found that, at times rains begin earlier in November, however, only few days or even one day has the rain, and is followed by a prolonged dry spell before the rains start again at the end of December or in January. This unpredictability tendency of the rains affected households' plans as to when they should grow their crops. The shortened rain season, forced communities to purchase and plant modern seeds with harvest circles. However, when they planted these seeds during early rains and the rains did not continue, the poor households could not afford to buy additional seeds as their stock ran out. Furthermore, it was revealed that the decline in rainfall was highly felt $(100 \%)$ because all people participated in farming and this had a close link to low productivity in the farms, and similarly the drying of rivers and pastures for livestock. Interviews also revealed that the increase warmth attracted diseases and pests for animals, livestock and people. Variability in rainfall through the study period (1980 -2010) is well illustrated in Figures 4 and 5, which show that rainfall intensity, onset and end of the rain season has changed hugely between early 1980s and towards 2010. The overall trend of the rains over the years is shown in Figure 2, which depicts the variations in rains over the years, and further illustrates that the variations are more acute starting from 1990s. This similar understanding was captured during key informant interviews with the elderly people. The correlation between perceptions that the communities have, based on their experience on the local environment and the studied climate data indicates the validity of the information, and provides basis to model climate trends and predict the outcomes in future if economic activities and growth rates remains the same. Figure 3 indicates that although overall temperatures have risen, the cold months have become colder and hot months are becoming hotter as well.

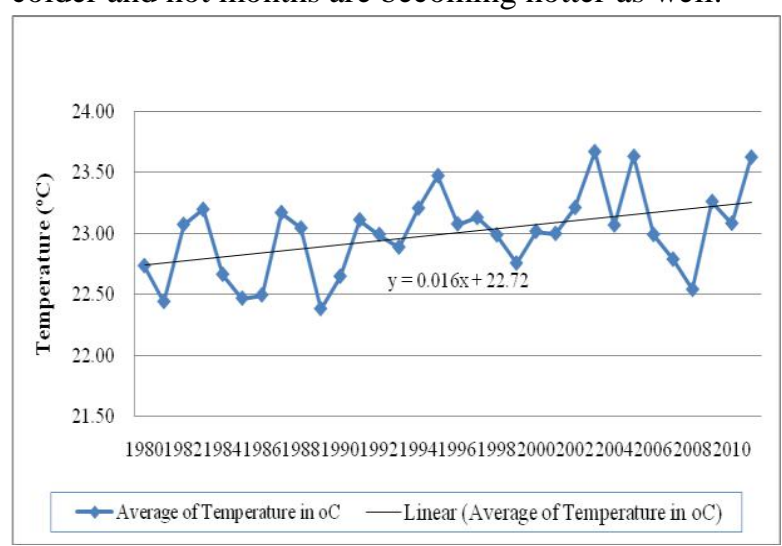

Fig.1: Average Temperature Trends in Chamwino from 1980 to 2010

Source: Fan Y., H. van den Dool (2004, 2008)

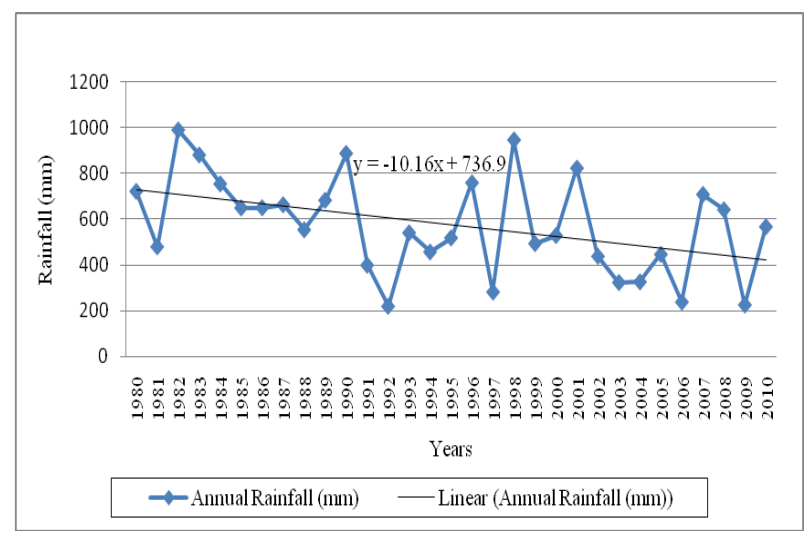

Fig.2: Total Annual Rainfall Trend from 1980 to 2010 
Source: Chamwino District Council, agriculture department

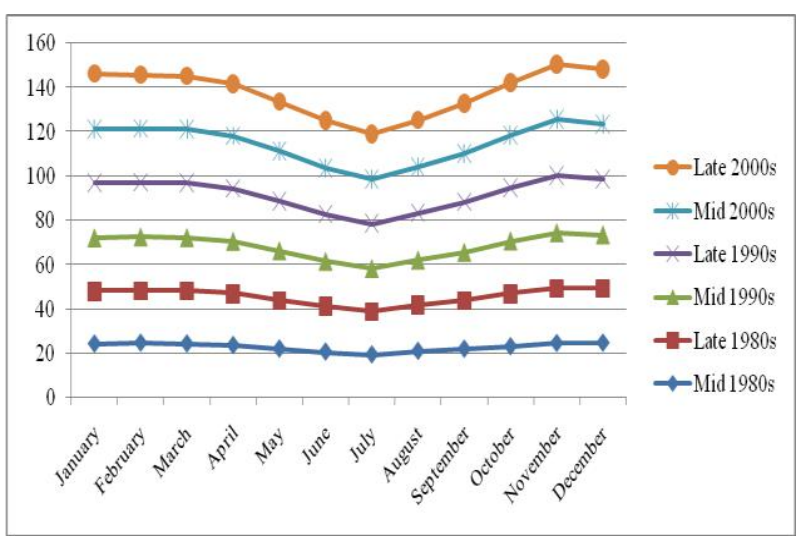

Fig.3: Five year temperature variations in Chamwino since $1980 \mathrm{~s}$

Source: Fan Y., H. van den Dool (2004; 2008)

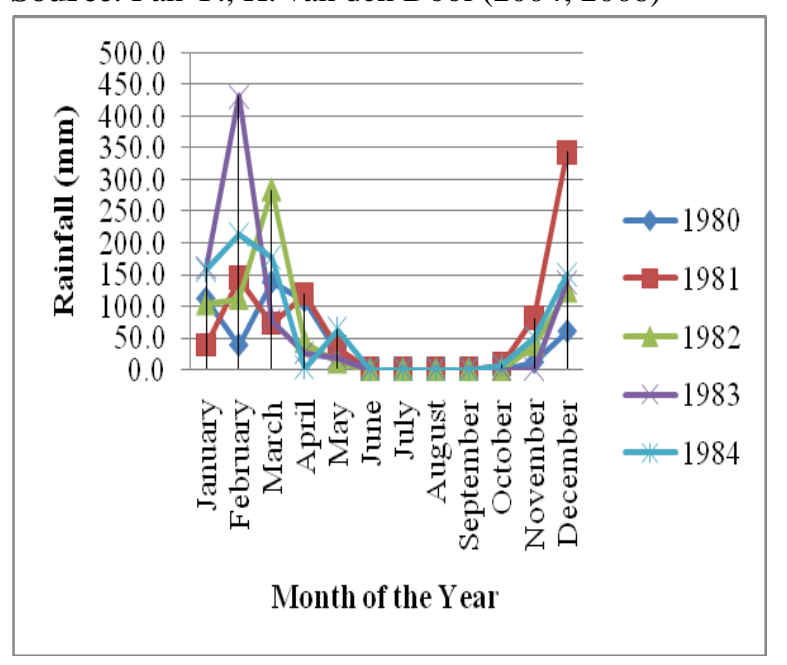

Fig.4: Total monthly rainfall (1980-1984)

Source: Chamwino District Agriculture Office.

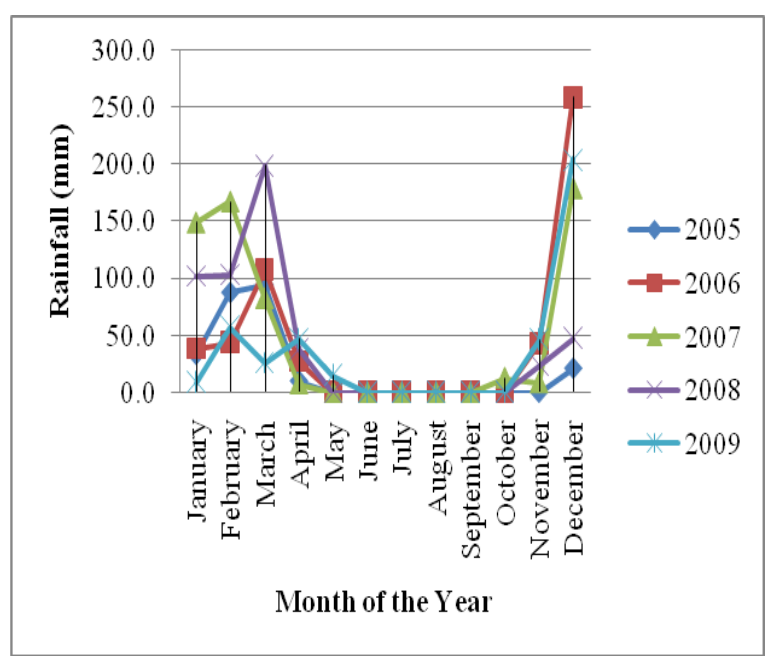

Fig.5: Total monthly rainfall (2005-2009).

Source: Chamwino District Agriculture Office.

This linkage between findings from socio-surveys and meteorological climate data analysis suggests a robust informal knowledge base possessed by the respondents. Therefore, local experience and knowledge deserves to be further exploited to create and improve scientific research on climate variability and climate change. Even with this note, male respondents seemed to be more knowledgeable about climate variability than females, probably because the male respondents had received higher education than females. This also indicated that the male respondents had combined their local experience with some formal education and exposure. It would thus appear that the community's level of understanding could shape the individual's perception on the cause or effects of climate risks. This finding somehow relates to the finding of Fabiyi et al. (2007), who concluded that education has the potential of making up some deficiencies in man as it enhances the understanding and communication in agriculture.

\section{A. 4.3 Impacts of Climate Change}

This study revealed several impacts due to climate change and variability on agriculture, livestock, water and forest resources as well as human beings. Respondents gave multiple responses when asked what they felt had been changing. In an order they indicated drought (54.6\%), decreasing pastures and grazing lands (42.3\%), animal and plant disease and pests and as well as human health problems. As a result of these, they reported that their produce in the farms were declining, and it was even worse in the years towards the end of the study period. Livestock were also decreasing due mostly to diseases. Others reported increased conflicts on resources and in households. People fought for water to feed their livestock during dry seasons because the same wells they dug for their livestock were also used for domestic water. Women and girls were most affected when compared to men because they had more roles (See also Table 1). This is because the roles are defined ethnically on gender basis. In this community all household chores are women responsibilities and men specialized more on livestock keeping and petty trade, including the sale of agricultural produce.

Due to early drying of water sources, water was obtained afar (normally 5 kilometres or more). This made it necessary for women to wake up very early to the well and spend 3 hours or more only to fetch one bucket of water because they carry it on their heads. Firewood, which was the source of fuel were now obtained afar as well because more areas have been cleared for faming due to increasing population and the need make big farms to offset crop failures. During dry season, men shifted to other villages in search for pasture or worked as labours in order to feed and find other needs for their families. A similar finding 
was also observed by Liwenga (2003). During discussions, it was revealed that, the majority of men who left their villages did not come back earlier as they had promised. Some of them married or cohabited with other wives, where they went, and the whole household responsibilities were left to their wives back home. During rainy season, water is not scarce, however, women did the majority of the farm work especially when hand hoes were used. During this time, women did the majority of cultivation, planting, weeding and harvesting whereas men did more of land clearing. The participation of men in paying jobs than those that aren't, was also revealed. At the same time, men kept money when they sold out their produce, and made most of the decisions without involving their wives. Table 7 presents distributions of roles and responsibilities by gender within households in the study area.

The perceptions on impacts were based on the skills and line of experience that a person had been exposed to earlier on. This is why, when women and men were asked separately what of the selected set of indicators had worst effects, their responses varied. For instance, male respondents were more concerned about loss of their animals that had been occurring in recent years due to eruption of diseases such as East Africa Fever, which were not common in previous years. On the other hand, female respondents were more concerned about the reduced crop yields in which they identified the past three years were the worst years in record in crop production where a farmer could not have any harvest. This also explains how people are sensitive to loss of their properties when threats from external factors occur.

Table.7: Distribution of roles and responsibilities in households (in \%)

\begin{tabular}{|l|l|l|l|l|l|}
\hline $\begin{array}{l}\text { Productive } \\
\text { work }\end{array}$ & Male & $\begin{array}{l}\text { Fem } \\
\text { ale }\end{array}$ & $\begin{array}{l}\text { Domestic } \\
\text { work }\end{array}$ & $\begin{array}{l}\text { Mal } \\
\text { e }\end{array}$ & $\begin{array}{l}\text { Fem } \\
\text { ale }\end{array}$ \\
\hline $\begin{array}{l}\text { Farm } \\
\text { preparation }\end{array}$ & 68.9 & 48.5 & $\begin{array}{l}\text { Fetching } \\
\text { water }\end{array}$ & 21 & 100 \\
\hline Cultivation & 95.6 & 87.9 & $\begin{array}{l}\text { Fuelwood } \\
\text { collection }\end{array}$ & 14 & 100 \\
\hline Planting & 86.7 & 97 & Cooking & 16 & 94 \\
\hline Harvesting & 88.9 & 97 & $\begin{array}{l}\text { Household } \\
\text { cleanliness }\end{array}$ & 4.7 & 94 \\
\hline Marketing & 91.1 & 78.8 & Baby sitting & 33 & 94 \\
\hline $\begin{array}{l}\text { Livestock } \\
\text { feeding }\end{array}$ & 37.8 & 6.1 & $\begin{array}{l}\text { Caring sick } \\
\text { house } \\
\text { members }\end{array}$ & 58 & 79 \\
\hline $\begin{array}{l}\text { Casual } \\
\text { works }\end{array}$ & 80 & 75.8 & $\begin{array}{l}\text { Breastfeedin } \\
\text { g }\end{array}$ & 0 & 100 \\
\hline
\end{tabular}

\begin{tabular}{|l|l|l|l|l|l|}
\hline $\begin{array}{l}\text { Bee } \\
\text { Keeping }\end{array}$ & 8.9 & 18.2 & Grinding & 2.3 & 94 \\
\hline & - & - & $\begin{array}{l}\text { Looking for } \\
\text { relish }\end{array}$ & 67 & 94 \\
\hline Totals & 558 & $\begin{array}{l}509 . \\
1\end{array}$ & Totals & 216 & 849 \\
\hline
\end{tabular}

Source: Own data from household Survey, May 2011

B. 4.4 Adaptation strategies to climate change

Several measures were taken to cope with effects of climate change and variability. These included the use of early maturing and drought-tolerant crop varieties; migrating with animals in search for new grazing land with good pastures; three-year interval deep ploughing with tractors, and ox-ploughs. All respondents (100\%) indicated that farming activities were being carried out by hand hoes, and $65.9 \%$ male and $60.6 \%$ female farmers were changing from using hand hoe to ox-plough while $34.1 \%$ and $21.2 \%$ were changing to tractors respectively. However, ox-ploughs and tractors were not used regularly. For instance $60 \%$ of women who had used a tractor or an ox-plough could not afford hiring it each year. Therefore, the majority of households tended to apply tillage by tractor or oxen after a certain time interval. This was used as an adaptation strategy to improve land productivity. Normally heavy tillage involving deep soil turning with a tractor or ox plough was applied once every three years. This would break the hard pan, increase water infiltration and conserved soil moisture. It also aided nutrient mixing, increased water retention from run-offs, soil aeration and microbial activity which aided quick plant growth and increased yields. Farmers who had used these strategies, reported to have seen improvement in their harvest.

Additionally, during key informant interviews, famers reported that they had to opt for an ox-plough or a tractor to reduce the workload. The new technology also helped them to cope with short and unpredictable rains. Even though, due to lack of knowledge, all respondents were unaware that in so doing, they were tackling effects of short and unpredictable rains and thus they were responding to climate variability; because they failed to explain why they had to use ox ploughs at least after every three years. According to Smit and Pilifosova (2001) this types of adaptation is described as reactive and autonomous, in which people respond to climate risks without a clear knowledge of the reasons why. The present study revealed that low productivity in the area was also caused by hardpan formation resulting from livestock movements, which needed heavy tilling and that would not be regulated by hand hoes. As such, machinery was needed to break the hard soils and increase soil turning, which enhanced the capacity of the soil by improving water retention and storage as well as bringing up nutrients 
to the subsoil essential for the early uptake of young seedlings.

Furthermore, farmers learnt that after the deep ploughing the farm does not take more than three years before it losses fertility and yields. On the other hand, this heavy tillage after three years was a strategy to reduce costs because the tractors and ox-ploughs were expensive to hire each year. On the other hand improved crop varieties, which are drought tolerant and resistant to diseases and pests, were being used.

Finally, it was further revealed that, the costs of adaptation were high. Nevertheless, some families (55.6\%) diversified by practicing both pastoralism and farming together. These were more adapted to climate shocks than those that did only farming or livestock keeping alone. This is because, when crops failed, they could sell their animals and could use this money to buy food from nearby villages. They also used manure from their livestock to improve soil fertility or were able to till their land more frequently with oxen they owned.

However, only male-headed households were found to keep livestock. Even when they were asked during focus group discussions, there were only female-headed households that were reported to own livestock in the study villages. Likewise, families that had larger portions of land were found to be able to adjust during climate shocks. For instance, some used their farms that are closer to river courses, which were moist. But the majority of these were male-headed households. Most of femaleheaded households $(63.6 \%)$ had smaller portions of land (less than 10 hectares), which means that they had to repeatedly grow crops on the same land, which finally lost its fertility. The reason was that, ethnically cattle and land are inherited to sons and not daughters. As a result of this, male-headed families had more options to adapt than female-headed families.

Additionally, the positive outcomes of climate variability that were found in the study area, such as business opportunities in commercial crops were taken up by wealthier households that had resources in place, such as a large amount of land or ox-ploughs, or those who could hire tractors. During divorce it was found that, wives did not inherit or receive a share of land or livestock from their ex-husbands. On the other hand the Tanzanian law requires that children younger than 7 years must stay with their mother before they live with their fathers. Therefore lack of resources increased threats to disadvantaged groups including women and the disabled. This supports argument by Olmos, (2001) that resource-rich households can be more resilient when risks or stresses occur.

\subsection{Socio Economic Implications of Climate Change}

There were direct and indirect social and economic consequences of impacts and adaptation strategies to climate change. The major ones included food insecurity, diseases, conflicts and increased workload in households. These issues hindered households' progress in different ways. Increased workload forced some children especially girls to drop off from studies in order to help their mothers with house chores. Likewise, when a married woman returns home late from fetching water or firewood that is caused by increased scarcity they would quarrel with their husbands. Young girls and boys were reported to migrate to small towns and Dodoma Municipal where they worked as waitresses in bars, or housemaids for girls and food and cloth vendors for boys. Because they did not have good education, they did not earn enough to feed themselves and their families back home. As a result it was reported that the majority of them ended up being prostitutes and were infected by sexually transmitted diseases such as HIV/AIDS. Furthermore, this copping strategy which involves migrating to other areas was highly practiced by men. Some men used this as an excuse to escape their family responsibilities, which were now left to their wives. Similar findings were obtained by Liwenga (2003) based on analysis of rainfall variability and mobility patterns in a semi-arid environment. This women to less active in social activities and had less time to rest when compared to men.

\section{CONCLUSION}

The study revealed clear evidences of climate change in the study area, as substantiated by people's perception and backed up by scientific climate data. Both of these suggest that, signs of climate variability started to be noticed in the early 1990s, particularly in 1992. Most common indicators in this area are a sharp decline in rainfall intensity, change in rainfall behaviour, its predictability, onset and end of the rain season. Also increase in warming whereby both day and nights were becoming hotter. These impacts have caused threats to livestock and farm produce that are a back borne to the economy of people in the study area. Women and men perceive and respond differently to the outcomes of climate variability, which follows their lines of experiences, and the roles they have been undertaking in their societies or households and which in return exposes them to different adaptation skills and experiences. This means that to effectively cope or adapt to threats of climate change adaptation strategies must take advantage of those skills in their totality and thus must involve both women and men at all stages. Responsible government institutions are advised to look into these varied dimensions. Furthermore, availability of resources enhances the ability to adapt, and thus women who had fewer resources were 
most negatively affected. Moreover, the immense local knowledge that communities have, if well utilized, can aid researchers to model climate trends and adaptation strategies for a long time. Furthermore, analysis of gendered roles must be undertaken to be able to understand the roles that are most adversely affected and appraise these to identify most plausible solutions.

\section{REFERENCES}

[1] Adger, W. N., Paavola, J., Huq, S., and Mace, M. J., 2006. Fairness in Adaptation to Climate Change. [ebook]. The Mit Press. Available on e-books at: http://wdn.ipublishcentral.net/mit/viewinside/1193486 48647. [Accessed 2nd April 2011].

[2] Brooks, N., 2003. Vulnerability, Risks and Adaptation: A Conceptual Framework. Centre Climate Change Research Tyndall Centre Working Paper No. 38.

[3] Chwamwino District Profile, 2011. Chamwino District council's updated District profile for 2010/2011.

[4] Eriksen S. H., Kelly P.M., \& Brown, K., 2005. The dynamics of vulnerability: locating coping strategies in Kenya and Tanzania. Geographical Journal vol. 171, No. 4.

[5] Fabiyi E.F., Danladi, B.B., Akande, K.E. and Mahmood, Y. 2007. Role of Women in Agricultural Development and Their Constraints: A Case Study of Biliri Local Government Area, Gombe State, Nigeria. Pakistan Journal of Nutrition vol. 6 (6): 676-680.

[6] Fan, Y., \& van den Dool, H., 2008. A global monthly land surface air temperature analysis for 1948-present, J. Geophys. Res., 113, D01103, doi:10.1029/2007JD008470.

[7] Fusel, M. H., \& Klein, R. J. T., 2006. Climate Change Vulnerability Assessments: An Evolution of Conceptual Thinking. Potsdam Institute for Climate Impact Research. Telegrafenberg, 14473 Potsdam.

[8] Heijmans, A., 2001. Vulnerability: A Matter of Perception. Benfield Greig Hazard Research Centre. University College of London.

[9] IPCC, 2001. Climate Change 2001: The Scientific Basis. Contribution of Working Group I to the Third Assessment Report of the Intergovernmental Panel on Climate Change. Houghton, J.T., Ding, Y., Griggs, D.J., Noguer, M., van der Linden, P.J., Maskell, X. Dai, K., \& C.A. Johnson, (eds.) 2001. Cambridge University Press. Cambridge, United Kingdom and New York, USA. 881pp.

[10] Kelly P. M., \& Adger, W.N., 2000. Theory and Practice in Assessing Vulnerability to Climate Change and Facilitating Adaptation. Kluwer Academic Publishers, Climatic Change, 47: 325-352.
[11]Kumar, K., 1989. Conducting Key Informant Interviews in Developing Countries._Agency for International Development.

[12] Lema, M. A \& Majule, A. E., 2009. Impacts of climate change, variability and adaptation strategies on agriculture in semi arid areas of Tanzania: The case of Manyoni District in Singida Region, Tanzania. African Journal of Environmental Science and Technology 3 (8), pp. 206-218. Available at http://www.academicjournals.org/AJEST [Accessed $23^{\text {rd }}$ October 2010].

[13] Liwenga, E.T. (2003). Food Insecurity and Coping Strategies in Semiarid Areas: The Case of Mvumi in Central Tanzania. Doctoral Dissertation, March, 2003. ISBN 91-22-02009-8.

[14] Liwenga, E.T. L. Kwezi and T. Afifi (2012). Rainfall, Food Security and Human Mobility: Case StudyTanzania. CARE \& UNU-EHS. Report No. 61. November 2012. ISBN: 978-3-939923-82-4

[15] Lyimo, J.G., and Kangalawe, R.Y.M. 2010. Vulnerability and adaptive strategies to the impact of climate change and variability. The case of rural households in semi-arid Tanzania. Environmental Economics, Vol 1(2). Also at: http://businessperspectives.org/journals_free/ee/2010/ ee_2010_2_Lyimo.pdf. [Accessed 22 $2^{\text {nd }}$ October 2011).

[16] Nelson, V., \& and Stathers, T., 2009. Resilience, power, culture, and climate: a case study from semiarid Tanzania, and new research directions. Gender and Development, 17 (1) pp. 81-94.

[17] Ngware, S. S. A., 1997. Gender and Agrarian Change in Tanzania, with a Kenya case study. [e-book]. DUP Ltd. Dar es salaam. Available at: http://www.abebooks.com/9789976602968/GenderAgrarian-Change-Tanzania-Kenyan-9976602960/plp. [Accessed $5^{\text {th }}$ January 2011].

[18] Ngigi, N. S., 2009. Climate Change Adaptation Strategies: Water Resources Management Options for Smallholder Farming Systems in Sub-Saharan Africa. The MDG Centre for East and Southern Africa of the Earth Institute at Columbia University, New York. 189p. Available at: http://www.rockefellerfoundation.org/uploads/files/9e acd477-e2ef-4b72-9207-5a18135dceb3.pdf. [Accessed $5^{\text {th }}$ June 2011].

[19] Olmos, S., 2001. Vulnerability and Adaptation to climate change: Concepts, Issues, Assessment Methods. Climate change knowledge network. Available at: www.cckn.net. [Accessed 22 $2^{\text {nd }}$ December 2011].

[20] Orindi, V. A., \& Murray, L., 2005. Adapting to Climate Change in East Africa: A strategic approach. 
Gate Keepers Series 117, International Institute for Environment and Development Available at: http://94.126.106.9/r4d/PDF/Outputs/ClimateChange/ Majule-and-Mary.pdf. [Accessed Accessed $5^{\text {th }}$ January 2011].

[21] Paavola, J., 2003. Vulnerability to Climate Change in Tanzania: Sources, Substance and Solutions: Jouni Paavola, CSERGE, University of East Anglia. Available at: http://enviro.lclark.edu/resources/EastAfrica/Climate/ Vulnerability.pdf. [Accessed $5^{\text {th }}$ January 2011].

[22] Parry, M.L., Canziani, O.F. \& Palutikof J.P., Eds., 2007. Climate Change 2007: Impacts, Adaptation and Vulnerability. Contribution of Working Group II to the Fourth Assessment Report of the Intergovernmental Panel on Climate Change. Cambridge University Press: Cambridge, UK, 23-78.

[23] Pasteur, K., 2002. Gender Analysis for Sustainable Livelihoods Frameworks, tools and links to other sources. Available online at: http://www.livestockemergency.net/userfiles/file/assessmentreview/Pasteur-2002.pdf, [Accessed 26 April 2011].

[24] Petermann, T., (Eds) 2008. Towards Climate Change adaptation-Building Adaptive Capacity in Managing African Trans Boundary River Basins. InWEnt, Zschortau, Germany.

[25] UN, 2005. Designing Household Survey Samples: Practical Guidelines. Series F, No. 98. New York.

[26] UNDP, 2009. Resource Guide on Gender and Climate change. United Nations Economic Commission for Africa. Available at: http://www.uneca.org/acpc/about_acpc/docs/UNDPGender-climate-change-resource-guide.pdf, [Accessed $3^{\text {rd }}$ November 2010].

[27] URT, 2003. Initial National Communication under the United Framework Convention on Climate Change. Vice President's Office. Also available online at: http://unfccc.int/resource/docs/natc/tannc1.pdf.

[28] URT, 2006a. National Population Policy. Ministry of Planning, Economy and Empowerment. Available at: http://www.tanzania.go.tz/pdf/Idadi\%20Eng.pdf. [Accessed $3^{\text {rd }}$ October 2011].

[29] URT, 2006b. National Adaptation Programme of Action. Available online at: http://unfccc.int/resource/docs/napa/tza01.pdf. [Accessed 21 ${ }^{\text {st }}$ June 2011].

[30] Yanda, P.Z., \& Mubaya, C. P., 2011. Managing a Changing Climate in Africa: Local Level Vulnerabilities and Adaptation Experiences. Dar es Salaam: Mkuki na Nyota Publishers Ltd.

[31] Rossi, A., \& Lambrou, Y., 2008. Gender and equity issues in Liquid biofuels production minimizing the risks to maximize the opportunities. 